\title{
Radicalization of Faith Concept in the School of Islam: Study of Khawarij and Muktazilah
}

\author{
Ramli Nur ${ }^{1}$ \\ ${ }^{1}$ Faculty of Social Science, Universitas Negeri Medan, Indonesia \\ Correspondence: Ramli Nur, Jl. Willem Iskandar Pasar V Medan Estate, North Sumatera, Indonesia. E-mail: \\ ramlinur17@gmail.com
}

Received: April 29, 2018

doi:10.5539/ass.v14n7p77
Accepted: June 2, $2018 \quad$ Online Published: June 22, 2018

URL: https://doi.org/10.5539/ass.v14n7p77

\begin{abstract}
The Radicalism is an idea or school that pursues revolution or social and political reforms in a tough or drastic way. The school of khawarij and muktazilah (two groups) have marked the history of Islamic thought about the concept of faith. The coloration shown tends to represent extremes in understanding the concept of faith. In general, it makes charitable deeds or branch teachings (furu') as part of the nature of faith. That leads to them getting caught in judging faith based on it being black or white between mukmin and kafir. Therefore the perpetrators of the great sins are punished out of Islam. Not merely categorization, but they also fighting and justifying of Muslims whom they consider to have abandoned the teachings of birth or violated something prohibited on the teaching of birth.

Such as of these understandings have mutated in the long history of the Muslims into the various nisbat mentions and often manipulate the religious as legitimacy for destructive radical actions. That is why this idea is quite dangerous not only at the beginning of its appearance but also in the current era to watch out for. This article has researched and analyzed the understandings of the two groups (Khawarij and Muktazilah).
\end{abstract}

Keywords: khawarij and muktazilah, radicalization of the concept of faith

\section{Introduction}

The discourse on faith in Islam is found in its basic of teaching (usulad-din). In Arabic, the word faith is understood lexically by "believing". Therefore, faith in Islamic ideologies is always positioned in the Islamic in the heart (qalb) (Abu Mansur al-Maturidi, $1365 \mathrm{H}$ ). In other words, faith is the inner element of the most elementary human (esoteric). However, a number of the Islamic ideologies are not satisfied for only placing faith in the inner element of ansich. They do not only place the faith in the inner of the element but also in the element of birth. The two of these ideologies are Khawarij and Muktazilah.

These two groups have given colors the history of Islamic thought about the concept of faith. The dyeing displayed tends to represent extremes in understanding the concept of faith. In general, they are making the charity of birth or the teachings of branch (furu') as part of the nature of faith. This attitude always traps them into looking in black and white between the believers and disbelievers. So that the perpetrators of the great sins are punished out of Islam, then on that they are certain to fight and justify the blood of Muslims which they see as having abandoned the teachings of birth or transgression.

These comprehension that have mutated in the long story of the Muslims into the various of nisbat mentioned and often manipulate religious terms such as jihad, al-amr bi al-ma'rufandnahyimunkar, law enforcement of qisas, and hudud as the legitimacy of violence and terror. That's why this understanding is quite dangerous not only in the era of its emergence but also in the current era. It is on this basis that this paper takes the role of racing the concept of faith according to these two to understand the mutation of radical understanding in Islamic school.

Khawarijare people who come out. This is what is understood literally. At the first the Khawarij was a political faction that separated itself from the ranks of 'Ali ibnAbiTalib (w. 40 H./661 M.). But this group eventually became a school of theology that has its own teachings that are different from the original early axial creeds. Its history began when there was a Siffin war between the forces of "Ali ibnAbiTalib and Mu'awiyyahibnAbiSufyan (w. $60 \mathrm{H} . / 680$ M.). The army of 'Ali ibnAbiTalib could force the armies of Mu'awiyah'sibnAbiSufyan who 
rebelled, so the latter are preparing to retreat. But for the powers of "Amribn al-'As who became one of Muawwiyah's advisors, so the historical direction was different. He proposed peace (tahkim) by brandishing the Qur'an with his spear into the air as a sign of peace (DediSupriyadi, 2008 M.).

By the blessed 'Ali ibnAbiTalib, the request of tahkim was responded positively after a deliberation with some of its troops. Subsequently, the arbitration is carried out, each side to dispute sends its representative. Ali ibnAbiTalib was represented by Abu Musa al-Ash'ari (w. 44 H./665 M) and the Mu'awiyyahibnAbiSufyan (w. 60 H./680 M.) was represented by Amribn al-'As (w. 43 H./663 M.). In the arbitration of Ali ibnAbiTalib was harmed by the strategy of Amr al-'As. Started from this is the emergence ofKhawarij groups in Islamic history. They argue that the battle can not be decided by human arbitration, but it must come from God, that returns to the laws of the Qur'an. Their famous remarks are, "La hukmaillalillah,"(Abu al Fadl 'Abbas ibn Mansur at-Tarini as-Saksaki al-Hanbali, 1996)taps the word of Allah in verse 57 of al-An'am.

Khawarij corresponds to its understanding of being an inner breakaway group. Since the events of tahkim, this group draws its loyalty and submission from 'Ali ibnAbiTalib (w. 40 H./661M.). They left Ali and his armies and migrated to Harura' near Kufa (Ab- al Fadl 'Abbas ibn Mansur at Tarini as-Saksaki al-Hanbali, al Burhan, h. 17). They saw that 'Ali ibnAbiTalib was guilty and committed him to fall into disbelief(Abu al-Hasan al-Asy'ari h.86). Ali ibnAbiTalib applied the bugah punishment for the rebels, not for the peace. The problems that occur in the political world that eventually led to the domain of faith. This cannot be denied, because since the beginning of Islam, it's not widely familiar with the concept of secularization that separates the affairs of the world and the hereafter or the affairs of temporality and spirituality. From the events mentioned above, arises in the theological discourse of categorizing the believers and unbelievers with a peculiar meaning. IbnTaymiyyah (w.728 H./1328 M.) states that the study of the two meaning of the words (faith and Islam) is the first internal research that occurs among Muslims(IbnTaimiyyah, Majmu'al-Fatawa, Juz VII, h. 169.). Because of this problem the Islamic community is divided into different sects in interpreting the Qur'an and Sunna. Thus, some refer to others as kaffir and vice versa(IbnTaimiyyah, Majmu', Juz VII, h. 169). However, the first group which entered thestage was Khawarij. The relevant question asked at the time is who is still a believer and who has disbelieved?

The objective political conditions have implications for theological understanding, and in return, theological teachings also have an effect on the political direction and color of Muslims. In this complicated issue, some early generations of friends in general cannot avoid being trapped into political chaos, because inevitably, they are involved in it and must respond to it as a religious and social responsibility. But the chaos was finally resolved at the momentum of 'Amm al-Jamaah. Nevertheless, its implications have sprouted its embryos and of Islam such as Khawarij, Murji'ah, Jabariyyah, Qadariyyah, and Syi'ah. Between theology and the other is a clash, not only at the war of doctrine but also bloodshed. But in this case Khawarij will be put forward at the beginning of the discussion because this groupwas the first to question the issue of faith(Toshihiko Izutsu,1994).

There are several titles (laqab) to give the identity of theKhawarij, that is al-Mariqah, which is related to the word of the Prophet about the people who will come out of Islam as the arrows shooting outof their bows; al-Hurriyah, is a place near Kufa which became their base after exiting from the army "Ali ibnAbiTalib; al-Muhakkimah, which is related to the events of tahkim between 'Ali ibnAbiTalib and Mu'awwiyahibnAbiSufyan in which the Khawarij says, "La hukmaillalillah" ; asy-Syira ', which is related to verse 207 of al-Baqarah surah where they believe that they sell themselves to seek Allah's pleasure; and al-Khawarij, which is related to their exit from the line of 'AbdibnAbiTalib (w. 40H./661 M.) as already mentioned(Ahmad ibn 'Atiyyahibn 'Ali al-Gamidi, h.79).However, this latter title is more popular in the literature history of Islamic theology.

In fact, the Khawarij group was split into several sects. Al-Bagdadi (w.429 H./ 1037 M.) writes 20 groups (Abd al-QahiribnTahiribn Muhammad al-Bagdadi, h. 54), as well as al-Asfirayaini (w. 471 H./1178 M.).)(Tahiribn Muhammad al-Asfiraiyaini, 1983), and Ahmad Jali(Ahmad Jali, h.52), while Ab-al-Fadl 'Abbas ibn Mans-r Tarini as Saksaki al-Hanbali wrote 18 firqah(Ab- al Fadl 'Abbas ibn Mans-r at-Tarini as-Saksaki al-Hnbali, h. 20), while Ab-al-Hasan al-Asy'ari (w.324 H/936 H.) notes that Ajaridah, one of the Khawaarij's stream reaches 15 streams(Ab- Hasan al-Asy'ari, h.93), has not been added other groups.

One of the problems when making the Khawarij as the object of study is related to the original literature derived from the Khawarij leaders. As Ammar at-Talibi says that Khawarij'sdid not survivefor the newer generations. Informations about theKhawarij that ulamaknowscame from critics written by people who disagree with them(IbnTaimiyyah VIII H.). The critical records can be objective and may also have bias from the subjectivity of the authors who have had a certain flow (Ammar at-Talibu, 1971). IbnTaymiyya (w. 728 H./1328 M.) says, "We know the Khawarij's thoughts only from the excerpts of the people who knows them. They never reach us, 
unlike the Mu'tazila, Rafidah, Zaidiyyah, Karramiyyah, Asy'ariyyah, Salimiyyah, followers of the four stream, 'ahiriyyah, the stream of Experts of Hadith, Ahl al Falasifah and Sufiyyah(IbnTaimiyah,; 'Ammar at Talibi, h. 137.)," these works are still found even as abundant as Asy'ariyyah.

Tosihiko says that the Khawarij or Kharijiyyah are the first group in the history of Islamic thought to raise the issue of faith as a theoretical problem seriously and theoretically. But he admits that it occurred indirectly because they were not theoretical neither are theologians when using the word theology in a technical sense, science of kalam(Toshihiko Izutsu, h.11.). Toshihiko's opinion must be understood in the sense that the Khawarij raised a debate about the meaning of faith and provided a different understanding from what was understood by Muslims at that the time of the previous era. Because, how could the newer generations not know this important issue and is the foundation in applying the Shari'a, both to the person and the congregation. The Companions have punished the Kaffir or the believer to a person or congregation which of course refers to the widely understood conception of faith and kufr. Prophet Muhammad said that faith is qaul and charity can increase and decrease as described in the discussion of previous generations in general. Abu Bakar against the groups of Musailamah al-Kazzab (w $13 \mathrm{H} . / 633 \mathrm{M}$ ) claiming to be prophets, as well as to groups denied of the obligation to pay zakat. This is proof that the terminology has been understood technically and applicable in the midst of Muslim leaders. In this connection, it can be justified if the Khawarij are a group that gives a different meaning and narrows the term space of faith in the history of Islamic theology.

\section{The Concept of Faith According to Khawarij}

The concept of faith according to the Khawarij is built on three pillars. First, justification in the heart (tasdiq bi al-jinan).second, oral recognition (iqrar bi al-lisan). Third, applied in the charity of the limb (amal bi al-jawarih)(Ahmad ibn 'Atiyahibn 'Ali al-Gamidi, h. 80).Apparently, this concept is not different from the previous Generation in general, but in the description and its application there is a fundamental difference. They see all good deeds as faith, whether fardu or sunnat. Included, in the meaning of faith according to their necessity to forsake every major sin. In the meantime, they see faith as a unified whole and cannot be decomposed. In other words, improper faith is divided into parts (la yatajaza). With a different phrase "Ammar at Talibi writes the relationship of charity with the following inner charity. Charity (as-sulk) is closely linked to the principle of religion (the principle of ad din) ie faith. If charity is an internal part in the formation of faith, then whoever leaves the charity or opposes the ban of gods has undoubtedly been deprived of the principle of faith (asl-iman)(Ammar at talibi, h. 138.).Due to an indivisible faith (la yataba'ad). Consequently all the internal elements of faith are the pillars of faith. When a person leaves one of these internal faiths he has in fact taken away all faith in him(Ammar at talibi, h. 138.). Therefore faith is permanent, not volatile. Thus, faith cannot increase and decrease. Logical consequence, when a person performs immoral therefore he has erased all the deeds that he did throughout his life and makes himself out of Islam (Ahmad ibn' 'Atiyahibn 'Ali al-Gamidi, h. 80.). This is what separates them from previous generations in general and Sunnahwaljama scholars. For the Sunna expert makes faiths unravels and fluctuate. Therefore according to the experts sunnah, immoral act does not cause a Muslim to become infidels as long as he acknowledged the immorality of the immoral. Likewise, leaving the obligation does not cause a person to become an infidel as long as he acknowledges the charitable obligation.

Khawarij does not divide sinners or sinners into great sins and minor sins. For this group all sin is a great sin. Every major sinner who dies in a state of no repentance then he dies pagan and eternal in the realm of hell(Ahmad ibn' 'Atiyahibn 'Ali al-Gamidi, h. 81.). Hence this group opens up very tight space for a person to be called a believer.

Al - asfirsayani (471/1178 AD) asserted that this group split into 20 groups but they all agreed in two respects. First, aliibnabitalib, usman, ashab al jamail, and all who joined the council and agreed tahkim is kafir. Secondly, every sinner from the people of the Prophet Muhammad, is a non believer and they are eternal in the realm of hell. In this case excluded group an-Najdat. For they say that the fasiq is non believer with the meaning of al-kufran (kufr favors) not with the meaning of al-kufr (out of Islam)(Tahiribn Muhammad al-asfirayani,h. 45). Nevertheless, al-ibadiyya who agreed on an-najdat in this regard justified the blood of the Muslims who disqualified their opinions. However, they still justify the slaughter of the Muslims outside of his group, marry the women, and inherit the tirkah (inheritance of properties) inherited by the Muslims(IbnHazm al-Andal -si, Juz III, h. 128.).

The violent attitude of the khawarij group causes them to be known as an extreme group with simple and uncompromising thought. They justified the blood and honor of other Muslims even though they were not classified as major sins. Because, according to them all sin is a great sin as mentioned. 
The proposition that they have set out to expel the great sinner of the faith is the verse 44 of al-Maidah; 'Al-imran 97; An- $N-r$ verse 55 as follows:

Allah says;

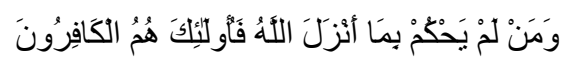

"Whoever is not condemned by what is revealed by Allah then they are the disbelievers." (Al - Maidah: 44)

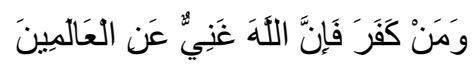

(Whoever denies (the obligation of Hajj), then truly Allah is rich (does not require anything) of the universe.) (Ali 'Imran 97).

$$
\text { وَمَنْ كَفَرَ بَعْدَ ذَلِكَ فَأُوِ للِكَ هُمُ الفَاسِيقُونَ }
$$

(And whoever remained unbelievers after that (promise), they are the wicked.) (Al-N-r: 55)

The verse above affirms literally the existence of pagan correlation with the sinners. On this basis khawarij classify the non believer is the perpetrators of the big sin.

Khawarijasibn Taimiyyah (w.728/1328 AD) sees that faith and Islam are identical. In other words, faith is Islam and Islam is faith (Ibn Taimiyah, h.356.). The same is stated by 'Ammar At-Talibi, Khawarij does not distinguish the meaning of faith and Islam. There is no separation in the teachings of i'tiqad and deeds. Their philosophy in this matter is the philosophy of the reality of amaliah ('Amaliyyahwaqiyyah), that is why they call the big sinner as non believer, polytheist or hypocrite (AmmarTalibi, h. 139-140).

If a khawarij group is found out of takfir in the problem of the big sinner, then it is a later development that adapts and softens the teachings.

\section{Knowing the Mu'tazila}

The Mu'tazilawere the rational schools of theology that first appeared in the history of Islam. The claim is present because the doctrine of its greater theology doctrine places the role of reason rather than the nas when compared to other ideologies. It can be said that the Mu'tazila was the real founder of kalam science, an adaptation between the literal and rational tradition, between thenas and the intellect, between the arab-Islamic treasury on one side confronted with Greek and Persian traditions on the other. Therefore almost every important thought in the science of kalam is found in the theological discourse of this genre. They discussed theological problems that had only been frozen in faith. The teachings of this theology were analyzed in terms of philosophical rationality. In addition to the study of aqidah, mu'tazilah also addresses matters of morality, politics, physics and metaphysics. They form a school of responsive thinking to the problems of God, nature, and man. The Mu'tazila discussed the problematics of al-kalam science in the first year of the 2nd century H. By various writers ofkalam, wasilbinj 'A-a' referred to as its founding father. He is a mawla birth of a madina who became a disciple of al-basri when teaching at the mosque of Iraq. Due to opposing opinions with the point he broke away from the hasan al-basri assembly and formed a new assembly. The mention of mu'tazilah to its stream according to some authors is due to its separation. The author Nazriyyah-at-Taklif explained that the issue of the position of the big sinner (murtakib al-kabirah) has sparked a fierce debate among the Muslims. Khawarij says that the big sinner is a kafir, Murji'ah says believer, and hasan al-basri said hypocritical. Hasan al-Basri's opinion is not approved by Wasil, he says that the big sinner is not a believer, not a non believer, and not a hypocrite, but a wicked one between two positions (al manzilahbain al-manzilatain)( Abd al-Karim 'Usman, 1971).

Qadi 'abd al-Jabbar explains that the Mu'tazila had five theological doctrines which became the basis of his teachings. The doctrine is called the proposal of Al-Khamsah, which is five basis consisting of at-tawhid doctrine; al-'adalah; al-wa'd and al-wa'id al-manzilahbain al-manzilatain and al-amr bi al ma'rufwa al-nahy 'an al-munkar (Qadi ‘Abd al-jabbar, 1965 M.).

Indeed, these principles appear in response to theological debates, especially among the Mu'tazilites of the other classes. Hence the formulation of usu-l al-khamsah is not permanent from the beginning, but appears gradually from the earliest mu'tazila genes to the later mu'tazila generation.

In essence, this school did not get widespread sympathy, but after the dynasty 'abbasiyah reigned the mu'tazilah's position was stronger, especially after the caliph al-makmin made the mu'tazilah view as the official school of the state. However, after the mihnah event lasts for a long time, the sympathy for this flow diminishes with less support from the authorities. Finally, this notion does not appear to the surface as an influential stream of nammun thus, according to HarunNasution in modern times and the rational science of Mu'tazila teachings 
re-emerged among Muslims, whether consciously or not (HarunNasution, h.60).

\section{The Concept of the Mu'tazilite Faith}

The basic concept of faith according to the Mu'tazila is similar to the Sunna Expert. It is mentioned that faith according to you "tazilah includes ma'rifah in the heart there is ad-din (religion of Islam), confession (iqrar) with oral, and charity with the members (Ab-Muhammad 'Ali ibnazm al-andal-si, h. 106). In the tabaqat al-Mu'tazilah it is mentioned that this definition is an agreement of the Mu'tazila sect (Ahmad ibnYahya al-murtada, h.8.). But their accentuation emphasizes the charity aspect. Therefore the mu'tazilahsay that every obedience and charity of goodness is faith, but they have differences in formulating and explaining it with other schools, especially experts of hadith. This is as described in Maqalat al-islamiyah by abu al-hasan al-asyari that the differences can be grouped into six opinions.

First, faith is to include all obedience, be it feminism or nafilah (Qadi 'Abd al-Jabbar, h.707.). Antonym from obedience is immoral. Immoral can be divided into 2 parts: 1 . An immoral which resulted in a small sin. 2. An immoral that resulted in a great sin. Meanwhile the great sin is broken down into two parts again, which is sin which implies disbelief for the culprit, and sin which does not cause unbelief. In here, man can become infidels due to three things, namely: one who is likening god to his creatures. Someone who thinks the law of God is unjust or he denied the information about the laws of Allah, a person who deals with the agreement of the Muslims that comes from his ni, either nass or taufiqi. In line with these three things, muktazilah also regard non believer people who say that Allah swt is jism, composed (mu'allaf) of the limbs, and dibatsa (mahd-d) in a certain size or capacity. Nevertheless they do not disbelieve someone who calls Allah as jism but does not give jism to him. For them substances are more important than designations and symbols. They also disbelieve those who say that Allah can be seen as he sees an object in the senses (al-mar'iyat) ,muqalabah (visavis) or mahaza (face to face) or it is somewhere while the other is in the different place. Mu'tazilahdisbelieve people who argue that Allah creates injustice or willed the ignorance, burden (taklif) to His creatures by means of something that the servant can not to do. Because it indicates that they assume God is stupid and do injustice by setting something to the weak. However, they do not label the disbeliever to who indicate the words for the one who is able to do taklif, then he says that Allah has imposed upon him when he cannot. In this case, he lies for saying substance capable is claimed incompetence, not lying to God in His taklif, and not giving to Him by saying that God has done wickedness. This opinion is attributed to Ab-Huzail's friends. That is why Ab-Huzail says that God forgives small sins for those who stay away from the great sins on the basis of virtue (tafaddul) not on the basis of right (istihqaq)(Abu al-Hasan al-Asy'ari, h.2006).

Ab-Huzail argues that all faith is believed in God. Some of these faiths have implications of kufr for those who have abandoned it, but some of them only for the wickedness. For example, defaulting prayers and fasting during Ramadan; some others will not cause disbelief and do not lead to ungodliness, only get a small sin if they leave it; some others do not eventuate to the kufr and neither drop someone into a vice, ie abandon the Sunnah(nawafil)(Abu al-Hasan al-Asy'ari, h 2006).

Second, the opinion ofHisham al-Fauti, he said that faith is all aspects of obedience, both fardu' and sunnah. He divides it into two parts: faith is caused by God (faith billah) and faith because of Allah (faith lillah). Faith is caused by God is anything that if someone abandoned it then he became infidels to Him. Faith because of God is when someone abandon it then he becomes infidel and can also just become ungodly instead of being infidels, such as prayer and zakat. That is, whoever abandoned his itiqad, this resulted in him becoming a kafir. But whoever abandons the obligatory with the conviction that abandoning the act is haram, then he simply falls into ungodliness. In the meantime, it is also found from his opinion that leaving the faith because God is only a small sin and does not result in ungodliness (Abu al-Hasan al-Asy'ari, h 266).

Third, the opinion of 'abbadibnSuliman, he says that faith is all about what is commanded by Allah swt, both fardiyyah and nafilah. According to him there are two forms of the faith. First, faith is caused by Allah (faith of billah), ie everything that if a person abandons it or leaves something from it then the person itself is a kafir, such as monotheism. Second, faith because of God (faith lillah), ie when someone leaves it then he is not the disbeliever one. In this realm the one who abandons it, is in digression and ungodliness. But it was also found that something that left behind only resulted a small sin. According to him, every act of the ignorant to God is kufr against Him (Abu al-Hasan al-Asy'ari, h.266).

Fourth, based on Ibrahim an-Nassam's view, faith is away from the great sins. The big sins are something that if it is done or not there is a threat for it $\left(a l-w a^{\prime} i d\right.$ ). Sometimes it is found in something that has no threat (by nass) but it is a great $\sin$ by Allah; and may not be a great $\sin$ too. Therefore faith in him is to stay away from any threats on the logic side of human and in the sight of Allah swt. If something has no any threat is a great sin, then 
it is called logical faith. Therefore a faithful person must know everything that has a threat according to human logic. While on the side of Allah swt, stay away from all the great sins is faith (Abu al-Hasan al-Asy'ari, h.266).

Fifth is an opinion that says that faith is to stay away from anything that has a threat on the side of human logic and the sight of Allah, ie everything contained in its title (al-ism). Anything that is classified into a small sin will be removed (magfur) by avoiding a great sin. Meanwhile, Muhammad ibn 'al-Wahhab al-Jubba'i said that faith in Allah is about all that God sends to his servants. Therefore, the charity of sunnat (nawafil) is not part of the faith.(Qadi 'Abd al-Jabbar,h. 707.). He also says that every aspect that is divested by God (faith of lillah) and includes faith in God (faith of billah). The wicked man in religion is a believer in the title of language (al-lugah asthma) because he does some of the faith.

Al-Jubba'i also argued that in the Jews there is a faith, so he named them as believers and Muslims in terms of language (asma al-lugah).The Mu'tazilah previously, -excluded al-Asamm- denied that the wicked were classified as Mukmim. They -as al-Jubba'i- argues that the wicked is neither Mukmin nor kafir, but it is between two places (manzilahbain al-manzilatain). Therefore he says that in the wicked man there is a faith but is not called as believer, also in the Jews there is faith but is not called as believer. Furthermore, sin is divided into two, namely small sins and big sins. If a person commits a small sin, he is entitled to God's forgiveness because he is away from the great sin. In the meantime, a great sin will erase the reward arising from faith, as avoiding a great sin will wipe out the punishment caused by a small sin. Furthermore, a strong desire (al-'azm) to commit a great sin is a great sin, a strong desire to commit a small sin is a small sin, and the desire to do kufr is kufr. This opinion is also the opinion of Abu Huzail(Abu al-Hassan al-Asy'ari, h. 266).

Sixth is the opinion of Ab-Bakr al-Asamm, he says that faith is all obedience. Whoever commits a great sin, then he is not called a kafir of the Islamic religion (ahl al-millah) but declared wicked for having committed a great sin. It is not called infidel nor hypocritical to those who believe in Allah's oneness (mu'min bi tauhidih) and do good deeds to obey Him. In the view of Abu Bakr al-Asamm, God calls something a faith even though the language is not said to be faith. Al-Asamm also said that there are differences of opinion in the Mu'tazilah's flow of small and large sins into three groups. The first group says that anyone who has a threat (al-wa'id) -in the nass- then it is a great sin. Anything that is not described threats then called a small sin. The second group, everyone who has a threat (al-wa'id) then it is a great sin. Likewise, everything that has something in common with something others that has threats is categorized into a great sin, even though there is no immediate threat to be described in the nass. Anything that is not described threats or something similar to it then there are two possibilities, which may be entirely a small sin and possibly some of them is great sins and some other is small sins. The third category is the opinion of Ja'faribnMubasysyir. He says that every sin committed intentionally is a great $\sin ($ Abu al-Hassan al-Asy'ari, h.266).

In general, the Mu'tazilahargue that Islam is identical with faith. Therefore faith is Islam and Islam is a faith. Thus if one says Islam then that is also faith and vice versa. These two pronunciations are made into one interchangeable meaning in their usage as contained in the Qur'an and Sunnah. The difference in this matter is only in the pronunciation not on the substance as Qadi 'Abd al-Jabbar puts it(Qadi 'Abd al-Jabbar, Syarh, h. 705), In support of his opinion he proposes a proof that the mention of Muslims is quoted from its lugah meaning, al-inqiyadwa al-istislam, to a new meaning, the meaning of syar'i. That is, a title for people who deserve praise and majesty (al-madhwa at-ta'zhim) as well as Mukmin's pronunciation. If the pronunciation is preserved in its original meaning (the meaning of lugawi) the Muslim term may also apply to the disbeliever when he submits and obeys to others, whereas it is not so(Qadi 'Abd al-Jabbar, Syarh, h. 705). Furthermore, Qadi 'Abd al-Jabbar filed to Suraal-Bayyinahverse 5 for the comparison :

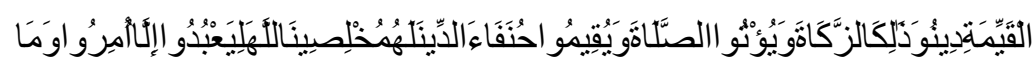

(But they are not enjoined except to worship Allah by purifying obedience to Him in straightening the religion, and so that they establish prayers and perform Zakat, and that is the righteous religion.)

This verse mentions the necessity of worshiping Allah purely, establishing shalat and issuing zakat called as din. If it is applied in term of lugah surely establishing shalat and issuing zakat are not included in term din but in this case the Qur'an calls itas din. Therefore, the pronunciation here has been interpreted by the meaningsyar'i, not the meaning of lugawi. Likewise, the pronunciation of Islam, is quoted from the meaning of lugah to the meaning of syar'i (Qadi 'Abd al-Jabbar h.705)

The identification of the meaning of faith and Islam syar'iyyah basically indicates the meaning of Islam was included in the meaning of the range of faith, namely tasdiq in the heart, oral words, and deeds of the body. Because the faith can increase and decrease, then Islam is the same. Caused in faith is rejected great sin then so 
islam. This is a logical consequence because faith is Islam and Islam is faith.

The Mu'tazilah discusses the condition of the fluctuations of faith, -that the existence of faith can increase and decrease- in the long angle taklif. In fact, humans have different levels of fulfillment in implementing taklif. For example is zakat. Zakat is only charged to people who have wealth that has reached a certain size of their wealth, while the needy and the poor can not do it. Standing in prayer is charged to a capable and healthy person to do so, while the sick person is not burdened like a healthy person. Likewise with the worship services such as hajj, and fasting, it is not the same as every human being. From this point of Mu'tazilah argues that a human being can differ inferiority between them. In this connection, Qadi 'Abd al-Jabbar proposed the argument of the Qur'an, ie Surah al-Anfal verse 3:

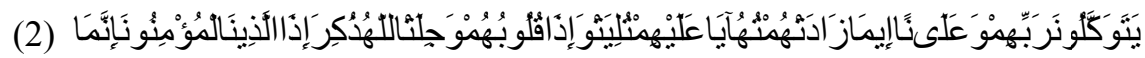

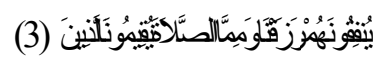

(The believers are only those who, when Allah is mentioned, their hearts become fearful, and when His verses are recited to them, it increases them in faith and who put their trust in their Lord. The ones who establish prayer, and from what We have provided them, they spend.)

In this verse, it is explained that faith can be increased. Something that can increase alsocancertainly be reduced. Therefore, faith can fluctuate. The expression of the above verse relates to something thatcan be different in making it happen. Something that can be embodied differently, of course among the perpetrators (mukallaf) can make it happen differently too, that someone can actualize it more than someone else. Based on this view, it is valid to say that faith can be increased and decreased. Unlike the case when the faith is a unity (khaslahwahidah) like oral words (al-qaul bi al-lisan) or i'tiqadis dedicated to the heart, it can not be shared. Something that can not be shared then has no increase and decrease ('Abd al-JabbaribnAhmad,h. 312-313).

\section{Radicalization of the Khawarij and Mu'tazilah Concepts of Faith}

Faith in the Qur'an and Hadith can be seen on two sides, namely the inward-oriented faith and the secondone is faiths that affirm the teaching of birth. This can be seen in the Qur'an surah al-Hujurat verse 14:

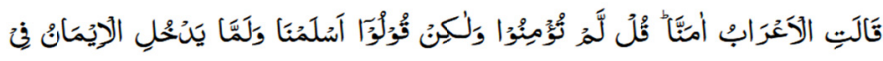

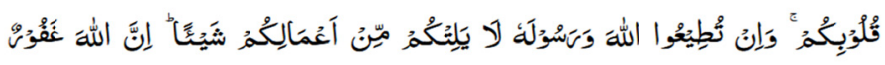

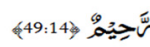

(The Bedouins say, "We have believed." Say, "You have not [yet] believed; but say [instead], 'We have submitted,' for faith has not yet entered your hearts. And if you obey Allah and His Messenger, He will not deprive you from your deeds of anything. Indeed, Allah is Forgiving and Merciful.")

Second, faith that is oriented to the meaning of $A d$-dinis the teaching which includes the aspects of the birth and the mind, for example in Al-Quran sura al-Anfal verse 4 below:

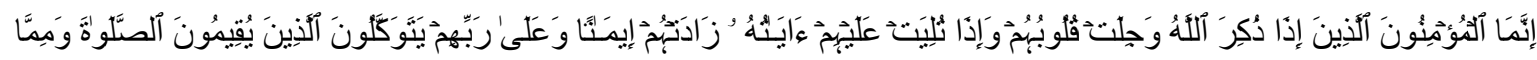

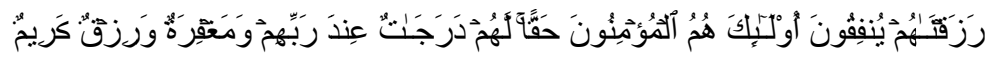

(The believers are only those who, when Allah is mentioned, their hearts become fearful, and when His verses are recited to them, it increases them in faith and who put their trust in their Lord. The ones who establish prayer, and from what We have provided them, they spend.) Those are the believers, truly. For them are degrees [of high position] with their Lord and forgiveness and noble provision.)

In a number of hadiths also found the meaning of faith that shows the inner dimension and born at once, for example following narration by al-Bukhari:

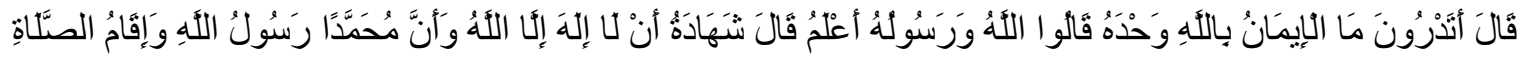

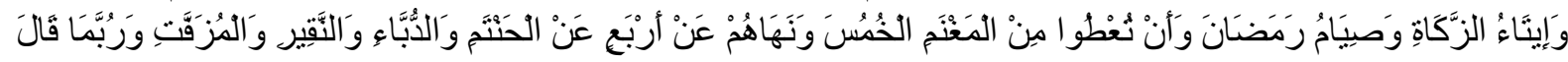

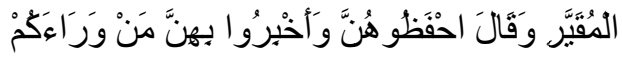

Prophet saw said: "do you know what faith means to Allah?" They replied: "Allah and His Messenger know better." The Prophet sallallaahu 'alaihiwasallam explains: The testimony there is no god except Allah and Muhammad is the messenger of Allah, establishing the prayers, pay alms, fast in the month of Ramadan and issue one fifth of the spoils of war....)(Al-Bukhari,h.20) 
From the quotation of verses from the Qur'an above found that faith can be applied to the meaning of birth and inner meaning as well.

The antonym of these two words, faith and Islam, iskufr. For example in the Quransuraal-kahf verse 29:

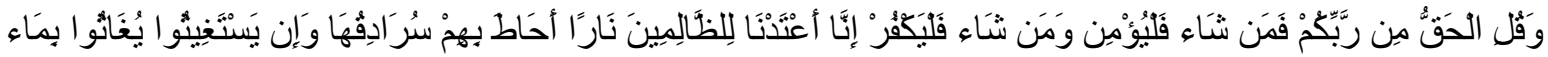

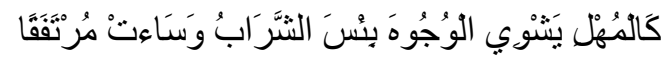

(And say, "The truth is from your Lord, so whoever wills - let him believe; and whoever wills - let him disbelieve." Indeed, We have prepared for the wrongdoers a fire whose walls will surround them. And if they call for relief, they will be relieved with water like murky oil, which scalds [their] faces. Wretched is the drink, and evil is the resting place.)

The difference in meaning to the terms of faith and Islam found in the naii, causing the majority of ulamas to distinguish the terminology of these two words and make it in a different domain of teaching.Faith becomes an inner teaching (esoteric) and Islam is a born (exoteric) doctrine (An-Nawawi, h.144-146). Thus, faith becomes a part of the essence of the doctrine (haqiqah) and Islam becomes the birth doctrine (shari'at).

However, unlike the Khawarij and Mu'tazilah that in application usage, the two terms have experienced an elaboration of meaning, especially faith. That is, the term faith is no longer understood as the inner teaching of ansich but has penetrated to the doctrine of birth. Finally, the meaning of the elaborated faith is used as the basic doctrine, which is as a consequence that faith is the basic doctrine. Therefore, when a person does not apply a doctrine or a part of the doctrine is born he is considered to have no faith, to be an apostate, or to disbelieve, as an antonym of mu'min. Therefore, if it is justified as an adage that faith or belief influences one's behavior, the expansion of the meaning of faith in theology also participates in that influx of influences; one of them is the radicalization of the teachings of the outward faith, so it is used as a benchmark of believers (mu'min) and disbelievers (kafir).

The radicalization referred above description is khawarij makes one narrow the criteria of the believer (mu'min) and extend the radical kafir. Therefore, claims such as a person who does not pray is a kafir; actors of democracy have canceled the faith; not punishable by Allah's law of infidels; People involved with the enforcement of non-constitutionalized Al-Quran and Sunnaare kafirs, and so on. This can arise from the radicalization of the teaching of the faith, which is used as a black and white measure to judge Muslims.

In fact the existence of accentuation of the meaning of faith in a certain realm has become a theological problem contributing to the emergence of influences within Islam. The most extreme flow in this case is the flow of takfiri, the group that convictsthedisbelieverof those who have been creed due to abandoning the mandatory teachings or doing something that is forbidden.

The most vulnerable theological schoolstrapped into the notions of takfiriis the schools that understands that faith haqiqi includes both inner and outer teachings. Because, when the birth deeds are regarded as part of the creed (basic doctrine), then abandoning it or breaking it certainly has implications for the injury of prominence. When charity is understood as a major part of belief, it reduces it to unbelief and excludes faith or it can disappear altogether. Faith is broken or gone will lead to disbelief and remove someone from the religion of Islam. The reasoning is quite clear, faith is the foundation that should not be damaged or lost as the teachings of other faiths. This is what happened in the Khawarij case, some of the Mu'tazilah followers. Although the Mu'tazilah used the teachings of al-manzilahbain al-manzilatain to keep them from convicting infidels, but in essence they expelled the perpetrators of the great sin of faith. Meanwhile, the Khawarij denounced the Muslims who committed absolute sins absolutely, even for the Companions of the Prophet.

Khawarij has been recorded in history as one of the radical groups that always threaten the rule of the Muslims. They narrow down the criteria of the believers and extend the scope of the kafir. Therefore, claims such as one who is not prayer is a kafir, not punishable by Allah's law of infidels; people involved with the enforcement of the non-constitutional State of the Qur'an and Sunnaiskafir, and so on. This may arise from the radicalization of the doctrine of the innate faith as a black-and-white benchmark to judge a person whether within the sphere of Islam or not. At the present time, Khwarij and Mu'tazilah thought at the level of its substance is still used as a concept of faith by the small part of the Muslims who ultimately very have the potential to become radical or supporters of radicalism.

\section{Conclusion}

The position of faith is always positioned in the Islamic schools within the basic teaching axis. However, some 
schools currents, such as the Khawarij and the Mu'tazilah, do not feel enough to place faith in the inner element of ansich. They place faith in other elements, inner but also outer substances. Caused, the concept of faith they formulate, these two groups, tend to represent extremes in understanding the concept of faith.

In general, the Khawaarij and the Mu'tazilah, making the charity of birth or the teachings of the branch (furu') as part of the nature of faith. Finally, they are caught in judging the faith in black and white between believers and disbelievers. Therefore the perpetrators of the great sins are punished out of Islam. Not merely categorization, but also they fight and justify the blood of Muslims whom they consider to have abandoned the teachings of birth or violated something forbidden on the teaching of birth.

Such understandings have mutated in the long history of Muslims into the various mentions and often manipulate the terms of religion as legitimacy for destructive radical action. That is why this understanding is quite dangerous not only in the early era of its emergence but also in the current era to watch out for.

\section{References}

Abd al-QahiribnTahiribn Muhammad al-Bagdadi. al-farqbain al-firaq.

Abu al-Fadl 'Abbas ibn Mansur at-Tarini as-Saksaki al Hanbali. al-Burhan fi Ma'rifah 'Aqa'idAhl al-Adyan (Ardan: Maktabah al-Manar, 1996).

Abu al-Fadl 'Abbas ibn Mansur at-Tarini as-Saksasi al-Hanbali, al-Burhan,tt.

Abu al-Fadl 'Abbas ibn Mansur at-Tarini as-Saksasi al-Hanbali, al-Burhan.

Abu al-Hasan al-Asy’ari. Maqalat.

Abu Mansur al-maturidi. SyarhFigh al Akbar (Jam'iyayahDa'irah al Ma'arif al-'Usmaniyyah: Haidar Abad, $1365 \mathrm{H})$.

Abu Muhammad 'Ali ibnHazm al-Andal-si. al-Fasl fi al-Milalwa al-Ahwa' wa an-Nihal(Maktabah al-Khanji: Kairo. tt), Juz III.

Ahmad ibn 'Atiyahibn 'Alial-Gamidi. 'Imanbain as-SalafwaKhalaf.

Ahmad ibnYahya al-Murtada. Tabaqat al-Mu'tazilah (Dar an-Nasr li Taba'ah: Kairo,tt.).

Ahmad Jali, ad-Dirasah 'an al-Firaq fi Tarikh al-Muslimin al-Khawarijwaasy-Syi'ah.

Ahmad, A. al-J. Mutasyabih al-Quran (Dar an-nasr li Taba'ah: Mesir,tt.).

Ali ibnAbiTalibmasukdalamgolongan yang dikafirkanKhawarij.Abu Hasan al-Asy'ari, Muqalat.

Ammar at-Talibi. Ara' al-Khawarij (Maktabah al Misri al-Hadis: Mesir, 1971). Juz I.

Dedi Supriyadi. SejarahPeradaban Islam (PustakaSetia: Bandung, 2008 M.)

IbnHazm al-Andal-si, al-Fasl fi al-Milalwa al-Ahwa'wa an-Nihal(Maktabah al-Khaniji: Kairo,tt), Juz III.

IbnTamiyah, Majmu'al-Fatawa, Juz VII.

Izutsu, T. (1994). The Concept of Belief in Islamic Theology: A Semantical Analysis of Iman and Islam. Terj Agus Fahri Husein (Tiara Wacaana: Yogyakarta).

Qadi ‘Abd al-Jabba. SyarhUsul al-Khamsah (MaktabahWalidah: Kairo, Mesir,1965 M.).

Qadi 'Abd al-Jabbar. Usul al-Khamsah.

Tahiribn Muhammad al-Asfirayani, at-Tabsir fi ad-Din waTamyiz al-Firqah an-Najiyah 'an al-Firaq al-Halikin $\left({ }^{\circ}\right.$ Iam al-Kutub: Beirut, 1983).

'Usman, A. al-K. (1971). Nasriyah at-Taklif (Mu'assasahar-Risalah: Beirut).

\section{Copyrights}

Copyright for this article is retained by the author(s), with first publication rights granted to the journal.

This is an open-access article distributed under the terms and conditions of the Creative Commons Attribution license (http://creativecommons.org/licenses/by/4.0/). 